Sains Malaysiana 50(3)(2021): 849-858

http://dx.doi.org/10.17576/jsm-2021-5003-25

\title{
Effect of Aging Heat Treatment on Corrosion Behavior and Corrosion Kinetics of 17-4PH Stainless Steel in Artificial Saliva
}

(Kesan Rawatan Panas Penuaan terhadap Tingkah Laku Kakisan dan Kinetik Kakisan Keluli Tahan Karat 17-4PH dalam Air Liur Buatan)

\author{
Onthida Kosasang*, Manutchaya WongKaeWmoon \& Somwan Chumphongphan
}

\section{ABSTRACT}

The corrosion behavior of the sintered 17-4PH stainless steel samples aged at different conditions in artificial saliva was studied using the method of electrochemical and weight loss after exposure for various periods of time. The results showed that the samples aged at $480^{\circ} \mathrm{C}$ for $1 \mathrm{~h}$ exhibited the highest corrosion resistance. The pitting corrosion was predominantly initiated from existing, isolated pores and further accelerated. The corrosion kinetics trend is found to be more consistent with a bimodal function form rather than the classical power-law function.

Keywords: 17-4PH stainless steel; artificial saliva; corrosion behavior; corrosion kinetics

\section{ABSTRAK}

Sifat kakisan sampel keluli kalis karat 17-4PH dalam air liur tiruan telah dikaji menggunakan kaedah elektrokimia dan kehilangan berat selepas terdedah pada jangka masa yang berbeza. Keputusan yang diperoleh menunjukkan bahawa sampel pada $480^{\circ} \mathrm{C}$ selama 1 jam mempunyai rintangan kakisan tertinggi. Kakisan pempitan adalah dominan bermula daripada liang yang sedia ada dan terus dipercepatkan. Corak kinetik kakisan didapati lebih berpadan dengan fungsi bimodal berbanding dengan fungsi hukum-kuasa klasik.

Kata kunci: Air liur tiruan; keluli kalis karat 17-4PH; kinetik kakisan; sifat kakisan

\section{INTRODUCTION}

The technological advancement of dental material has evolved to meet an increased demand for materials with high durability and high biocompatibility. 17-4PH stainless steel is a precipitation hardening alloy that is a highly desirable material for orthodontic brackets in dentistry. It has a good combination of high strength, high toughness and good corrosion resistance (Costa et al. 2006; Liu et al. 2018; Zhang \& Chu 2012). Metal Injection Molding (MIM) technique plays an important part in the production of 17-4PH stainless steel with numbers of advantages including complex shape, minimal machining, and high volume production. Most orthodontic brackets used in dental application are currently made of 17-4PH stainless steel and fabricated by MIM. The main procedures of the MIM process involve mixing metal powders and polymer feed stock, injection molding, debinding, and sintering, respectively. Previous investigations (Manonukul et al. 2007; Wu et al. 2002; Zhang 1992) concluded that to obtain full or near-full density and high mechanical properties in
17-4PH stainless steel the sintering temperature of 1300$1350{ }^{\circ} \mathrm{C}$ is used. The disadvantage of sintered $17-4 \mathrm{PH}$ stainless steel compared to wrought is the residual pores that can deteriorate mechanical properties (Gülsoy et al. 2004; Suri et al. 2006; Szewczyk-Nykiel 2014) and corrosion resistance. Sobral et al. (2001) observed the tendency of pitting corrosion in sintered $17-4 \mathrm{PH}$ stainless steel in $3 \%$ $\mathrm{NaCl}$ solution. Moreover, chromium evaporation on the surface during sintering process can also degrade corrosion resistance.

In oral environment, localized corrosion of orthodontic brackets made from this material still occurs as saliva contains aggressive chlorine ions (Cl-). The $\mathrm{pH}$ can be varied depending on age, eating habit, and oral hygiene (Escobar et al. 2017; Renita et al. 2017). Moreover, food trapped in the bracket can accumulate bacteria, producing dental plaque. The acid produced from dental plague subsequently causes the deterioration of enamel, and dental decay. The corrosion process can also affect the performance of orthodontic brackets. 
Precipitate aging treatment is a process to strengthen $17-4 \mathrm{PH}$ stainless steel by precipitating very fine copperrich phase. The variation of temperatures and times cause the difference in mechanical properties and corrosion resistance. Szewczyk-Nykiel and Kazior (2017) reported that corrosion rate of MIM 17-4PH stainless steel, sintered at $1340{ }^{\circ} \mathrm{C}$, in $0.5 \mathrm{M} \mathrm{H} 2 \mathrm{SO} 4$ solution is reduced as the ageing temperature is increased from 480 to 500 ${ }^{\circ} \mathrm{C}$. Shoushtari (2010) reported that corrosion resistance of wrought $17-4 \mathrm{PH}$ stainless steel to pitting increases as ageing temperature increases from 480 to $550{ }^{\circ} \mathrm{C}$ in $3.5 \%$ $\mathrm{NaCl}$. However, the corrosion resistance to pitting declines as ageing temperature approaches $620^{\circ} \mathrm{C}$. Raja and Prasad (1995) stated that solution annealing at $1050^{\circ} \mathrm{C}$ followed by aging at $480{ }^{\circ} \mathrm{C}$ resulted in the highest corrosion resistance in wrought $17-4 \mathrm{PH}$ stainless steel. Though the heat treatment process does not affect corrosion resistance significantly.

To the best of our knowledge, very limited work is available on the corrosion behavior of sintered 17$4 \mathrm{PH}$ stainless steel. This study aims to investigate how different aging treatments influence the corrosion behavior and corrosion kinetics in sintered 17-4PH stainless steel samples in artificial saliva.

\section{MATERIALS AND METHODS}

17-4PH stainless steel samples were fabricated by metal injection molding (MIM) and sintered at $1325^{\circ} \mathrm{C}$ for $2 \mathrm{~h}$. The density of as-sintered sample (SS) is $7.5 \mathrm{gcm}^{-3}$. The chemical compositions examined by X-ray fluorescence (XRF) technique (HORIBA, MESA-500W) are shown in Table 1. Three different ageing heat treatments were performed. All samples were subjected to a solution heat treatment at $1040{ }^{\circ} \mathrm{C}$ for $1 \mathrm{~h}$ followed by air cooling. The aging treatments were performed at $400{ }^{\circ} \mathrm{C}$ for $1 \mathrm{~h}$ (SS400), $480{ }^{\circ} \mathrm{C}$ for $1 \mathrm{~h}$ (SS480), $620^{\circ} \mathrm{C}$ for $4 \mathrm{~h}$ (SS620) and followed by air cooling. Phase compositions of all conditions were identified by the X-ray diffraction technique (XRD, Analytical X'Pert Pro MPD).
Prior to corrosion test, all samples were ground with silicon carbide papers followed by polishing with diamond pastes down to the powder size of $1 \mu \mathrm{m}$. The corrosion was measured using an immersion test and electrochemical method in artificial saliva. The composition of the artificial saliva is shown in Table 2. For immersion test method, all samples were weighed prior to the immersion test. The samples were then immersed in artificial saliva under stagnant conditions. The samples were then weighed at different immersion periods $(1,2,4$, $6,8,10$, and 12 weeks). The weight loss per unit area (W), and corrosion rate (CR) were calculated using (1) and (2), respectively.

$$
\begin{gathered}
\mathrm{W}=\frac{\mathrm{W}_{\mathrm{i}}-\mathrm{W}_{\mathrm{f}}}{\mathrm{A}} \\
\mathrm{CR}(\mu \mathrm{m} / \text { year })=\frac{\mathrm{W}}{\mathrm{Adt}}
\end{gathered}
$$

whereas $\mathrm{W}$ is weight loss per unit area in $\mathrm{gm}^{-2}, \mathrm{~W}_{\mathrm{i}}$ is weight before immersion test $(\mathrm{g})$, and $\mathrm{W}_{\mathrm{f}}$ is weight after immersion test (g). Furthermore, A is surface area $\left(\mathrm{m}^{2}\right), \mathrm{d}$ is density of sample $\left(\mathrm{gcm}^{-3}\right)$, and $\mathrm{t}$ is immersion time (year). The surfaces of the aged samples before and after immersion test were observed using a scanning electron microscope (SEM, 1450 VP LEO).

For electrochemical method, potentiodynamic polarization measurement were performed in a threeelectrode cell (AUTOLAB). $\mathrm{Ag} / \mathrm{AgCl}$ and graphite were used as reference electrode and counter electrode, respectively. Samples were immersed in the artificial saliva solution for $1 \mathrm{~h}$ at room temperature to provide a steady open circuit potential prior to the polarization test. Polarization was scanned from -200 to $200 \mathrm{mV}$ using scanning rate of $0.01 \mathrm{Vs}^{-1}$. Corrosion potential $\left(\mathrm{E}_{\text {corr }}\right)$, corrosion pit potential $\left(\mathrm{E}_{\mathrm{pit}}\right)$ and current density $\left(\mathrm{I}_{\text {corr }}\right)$ of each sample were evaluated from polarization curves.

TABLE 1. Chemical composition of the 17-4PH stainless steel

\begin{tabular}{cccccccc}
\hline Element & $\mathrm{Fe}$ & $\mathrm{Cr}$ & $\mathrm{Ni}$ & $\mathrm{Cu}$ & $\mathrm{Si}$ & $\mathrm{Al}$ & Others \\
\hline Composition (\%) & 76.21 & 16.15 & 3.95 & 2.27 & 0.70 & 0.67 & 0.05 \\
\hline
\end{tabular}

TABLE 2. Artificial saliva composition

\begin{tabular}{ccccccc}
\hline $\mathrm{NaCl}$ & $\mathrm{NSCN}$ & $\mathrm{NaHCO}_{3}$ & $\mathrm{KCl}$ & $\mathrm{Urea}$ & $\mathrm{Na}_{2} \mathrm{HPO}_{4}$ & $\mathrm{KH}_{2} \mathrm{PO}_{4}$ \\
\hline $0.70 \mathrm{gL}^{-1}$ & $0.33 \mathrm{gL}^{-1}$ & $1.50 \mathrm{gL}^{-1}$ & $1.20 \mathrm{gL}^{-1}$ & $0.13 \mathrm{gL}^{-1}$ & $0.26 \mathrm{gL}^{-1}$ & $0.20 \mathrm{gL}^{-1}$
\end{tabular}




\section{RESULTS AND DISCUSSION}

\section{PHYSICAL PROPERTIES CHARACTERIZATIONS}

The XRD patterns of the as-sintered and aged samples are presented in Figure 1. The XRD peaks match well with Fe (JCPDS no. 01-085-1410). It can be observed that aging temperatures and times do not influence the phase of 174PH stainless steel. Figure 2 shows optical micrographs of as-sintered sample (Figure 2(a)) and aged samples (Figure 2(b)-2(d)). The microstructure of all samples contains martensite and $\delta$-ferrite. No distinct change is presented after aging heat treatment.

\section{TIME DEPENDENCE OF WEIGHT LOSS IN IMMERSION TEST}

Figure 3 shows time dependence of weight loss per area $\left(\mathrm{gm}^{-2}\right)$ of $17-4 \mathrm{PH}$ stainless steel aged at different ageing conditions immersed in artificial saliva. It is observed that there is a rapid increase in weight loss from week 1 to week 2 in all conditions. This may arise the low chromium $(\mathrm{Cr})$ content on the surface of MIM sample leading to the rapidly reduction of the initial passive film (He \& Jiang 2018). The weight loss plateaus from week 2 to week 8 , but any further increases in immersion time progressively increase weigh loss per area. The plateau of weight loss per area indicates that the passive film is in a steady state, where the growth and the dissolution of the passive film is in a dynamic equilibrium ( $\mathrm{Li}$ et al. 2020). After week 10, another noticeable change in weight loss was observed.

The corrosion rate calculated from (2) is illustrated in Figure 4. The decreases of corrosion rate with any increase in immersion time were noticed. This is due to the formation of a thicker passive layer in 17-4PH stainless steel. However, this passive layer is not truly passivated. It acts as a membrane. The presence of $\mathrm{Cl}$ - ions in aqueous solution can penetrate this layer locally (Al-Moubaraki \& Al-Rushud 2018; Al-Moubaraki et al. 2014; Frankel 1998).

Several studies have indicated the precipitation of the $\mathrm{Cu}$-rich phase of 17-4PH stainless steel altered as aging temperature and time changed. Viswanathan et al. (1988) stated that the formation of $\mathrm{Cu}$-rich precipitate began at an aging temperature above $470{ }^{\circ} \mathrm{C}$ and the precipitate size increase and become incoherent with further aging temperature. Chung and Tzeng (2019) observed fine spherical precipitate of $\varepsilon$ - $\mathrm{Cu}$ phase with a size less than 10 and $40-100 \mathrm{~nm}$ dispersed on the matrix after aging at 480 and $620^{\circ} \mathrm{C}$, respectively. It has been identified that peak age condition of $17-4 \mathrm{PH}$ stainless steel is at $480{ }^{\circ} \mathrm{C}$ for $1 \mathrm{~h}$, where the ultra-fine coherent copper precipitate can effectively obstruct the movement of dislocations and thereby enhance the strength of $17-4 \mathrm{PH}$ stainless steel (Chung \& Tzeng 2019; Hsiao et al. 2002; Yoo et al. 2006). In our study, the Vicker microhardness (HV) of SS, SS400, SS480 and SS620 are 292, 317, 410 and 314 , respectively. Therefore, the SS, SS400, SS480, and SS620 are corresponding to as-sintered, underaged, and overaged condition, respectively. The $\mathrm{Cu}$-rich precipitate in as-sintered sample, underaged (SS400), peak-aged (SS480), and overaged (SS680) samples is hypothetically illustrated in Figure 5.

Obtained results demonstrate that the corrosion rate of as-sintered sample is likely to be higher than those samples subjected to aging treatments. This is because aging treatment relieves stress of the martensite matrix (Mudali et al. 1990). The corrosion rate of underaged sample (SS400) is considerably lower than the corrosion rate from as-sintered sample as early stage precipitation occurs. Among all heat-treated conditions, peak-aged samples (SS480) show the lowest corrosion rate. These results are in concordance with several other corrosion behavior studies in 3.5\% NaCl (Shoushtari 2010) and 0.5 M H2SO4 (Szewczyk-Nykiel \& Kazior 2017). The high corrosion resistance in peak-aged sample may be attributed to fine and coherent $\mathrm{Cu}$ rich precipitate in the microstructure. This can lead to a more stable passive film. On the other hand, the overaged sample (SS620) exhibits the highest corrosion rate. High temperature and long aging time lead to the agglomerated precipitates, which can stimulate nucleation sites for revert austenite (Murayama et al. 1999). As a consequence, galvanic coupling can be formed. Moreover, it was reported by Ziewiec et al. (2014) there was a segregation of chromium at the grain boundaries, promoting the M32C6 precipitates at the aging temperature of $620^{\circ} \mathrm{C}$. Lower chromium content causes the decrease in corrosion resistance.

\section{CORROSION SURFACE AFTER IMMERSION TEST}

Figure 6(a) shows a SEM image of a typical surface of as received $17-4 \mathrm{PH}$ stainless steel. The surface contains isolated small pores with a diameter of less than $3 \mu \mathrm{m}$. The SEM images of Figure 6(b)-6(e) show surfaces of unaged samples and the three different heat-treated samples after 12 weeks of immersion. It is observed that $17-4 \mathrm{PH}$ stainless steel deteriorates from localized corrosion. The sizes of corrosion pit after 12 weeks immersion is in a range of $15-50 \mu \mathrm{m}$. Moreover, the corrosion sites are more likely initiated from existing isolated residual pores, which could cause a discontinuous protective film. The corrosion may occur on surface inside, where there is no protective film, and act as the anode, while the sample surface is the cathode. Deep and large pits were observed in SS, SS400, and SS620, while relative shallower pit was observed in SS480. This observation corresponds well to the corrosion rate reported in the previous section. 


\section{CORROSION KINETICS}

The kinetics of corrosion in wet solution is commonly quantified using the power law. In this approach, the weight loss per area (W), after a time (t) is given by (3)

$$
\mathrm{W}=\mathrm{At}
$$

whereas $\mathrm{t}$ is an immersion time (year), and $\mathrm{n}$ is the corrosion constant. Equation (3) may be rewritten in a form that is convenient for analysis and is given (4).

$$
\log \mathrm{W}=\log \mathrm{A}+\mathrm{n} \log \mathrm{t}
$$

The fitting was applied by performing a linear fit produced by Equation 4 as illustrated in Figure 7 . The solid shapes in the plot correspond to the first segment of the graph, while the open shapes represent the second segment of the graph. Their slope and interception are used to determine the value of corrosion constant $\mathrm{n}$ and $\mathrm{A}$ (weight loss after 1 year), respectively. It was found that the log-log plot date was not consistent with the power law model. In this case, a discontinuous line consisting of two linear segments seem to be better fit than a single trend line. This is similar to the observations of Melchers (2019, 2014) who stated that the power law function is limited to the short-term corrosion loss. Instead, the bimodal trend is more applicable to long-term corrosion.

The slopes of the first and second segment are referred to as $n 1$ and n2, respectively. As shown in Table 3, the slope of the second segment (n2) is higher than that of the first segment (n1) in all conditions. Generally, the corrosion mechanism may be quantitatively interpreted using a corrosion constant (n) (Morcillo et al. 2013; Wang et al. 1997). In the first segment, the $n 1$ values are in a range of $0.09-0.16$, which is less than 0.5 . This suggests that the diffusion process decreases due to the fact that the corrosion product layer becomes more compact with time. On the contrary, the $\mathrm{n} 2$ values are in a range of $0.55-1.15$, which is greater than 0.5 . This indicates the corrosion is faster than the diffusion process, as the corrosion product detaches by cracking, dissolution, and erosion. This corrosion kinetics behavior could be related to the discontinuous passive film as a result of existing pores. Under the first stage, the small pit acts as a small anode, while the large surrounding surface act as a cathode. As a result, the metal ions are produced at an accelerated rate. The possible anodic reactions inside the pit are as follows:

$$
\begin{aligned}
& \mathrm{Fe} \rightarrow \mathrm{Fe}^{2+}+2 \mathrm{e}^{-} \\
& 3 \mathrm{Fe}+4 \mathrm{H}_{2} \mathrm{O} \rightarrow \mathrm{Fe}_{3} \mathrm{O}_{4}+8 \mathrm{H}^{+}+8 \mathrm{e}^{-} \\
& \mathrm{Fe}^{2+}+\mathrm{H}_{2} \mathrm{O} \rightarrow \mathrm{Fe}(\mathrm{OH})^{+}+\mathrm{H}^{+} \\
& 3 \mathrm{Fe}(\mathrm{OH})^{+}+\mathrm{H}_{2} \mathrm{O} \rightarrow \mathrm{Fe}_{3} \mathrm{O}_{4}+5 \mathrm{H}^{+}+2 \mathrm{e}^{-}
\end{aligned}
$$

At the second stage, due to the presence of anions $\left(\mathrm{Cl}^{-}\right)$ in artificial saliva, $\mathrm{Cl}^{-}$ions migrate into the pit area and lead to the formation of hydrogen ions $\left(\mathrm{H}^{+}\right)$. The possible hydrolysis reactions are shown below herewith.

$$
\begin{aligned}
& \mathrm{Fe}^{2+}+\mathrm{Cl}^{2-} \rightarrow \mathrm{FeCl}_{2} \\
& \mathrm{FeCl}_{2}+\mathrm{H}_{2} \mathrm{O} \rightarrow \mathrm{Fe}(\mathrm{OH})^{+}+\mathrm{H}^{+}+2 \mathrm{Cl}^{-} \\
& \mathrm{Fe}^{2+}+\mathrm{H}_{2} \mathrm{O} \rightarrow \mathrm{Fe}(\mathrm{OH})^{+}+\mathrm{H}^{+}
\end{aligned}
$$

Moreover, a corrosion product (i.e. $\mathrm{Fe}_{3} \mathrm{O}_{4}$ ) can flake off and leave fresh metal surface exposed to the corrosive media. As a consequence, further dissolution occurs. However, in our study, the flake off of corrosion product was not observed.

\section{ELECTROCHEMICAL MEASUREMENT}

Polarization curves of the 17-4PH samples aged at different conditions in artificial saliva are shown in Figure 8. The corrosion potential $\left(\mathrm{E}_{\text {corr }}\right)$, pitting potential $\left(\mathrm{E}_{\mathrm{pit}}\right)$, and corrosion current density ( $\left.\mathrm{I}_{\text {corr }}\right)$ were extrapolated and summarized in Table 4. The $\mathrm{E}_{\text {corr }}$ value of SS480 is higher $(-0.56 \mathrm{~V})$ than that of SS $(-0.90 \mathrm{~V}), \mathrm{SS} 400(-0.87 \mathrm{~V})$, and SS620 $(-0.89 \mathrm{~V})$, indicating the SS480 is more noble than the others. Moreover, the $\mathrm{I}_{\text {corr }}$ of SS480 is the lowest $\left(0.28 \mu \mathrm{Acm}^{-2}\right)$ and is approximately 10 times lower than other samples. The low $\mathrm{I}_{\text {corr }}$ indicates the low corrosion rate of the SS480 sample. This result is quite consistent with our corrosion rate results and other literatures. Szewczyk-Nykiel and Kazior (2017) observed the decrease in corrosion potential as aging temperature increased from 480 to $500{ }^{\circ} \mathrm{C}$ in $0.5 \mathrm{M} \mathrm{H}_{2} \mathrm{SO}_{4}$ solution. However, our corrosion potential values are higher than their report. This may arise different in number of residual pores from different in sintering condition of MIM process. As far as corrosion resistance to pitting, the SS sample shows the lowest resistance to pitting while SS480 shows the no pitting resistance as passivation occurs. This result, however contradict the observation of Shoushtari (2010) who reported that corrosion resistance to pitting increases as ageing temperature increases from 480 to $550{ }^{\circ} \mathrm{C}$ in $3.5 \%$ $\mathrm{NaCl}$ in wrought $17-4 \mathrm{PH}$ stainless steel. The discrepancy of our results (corrosion potential $\left(\mathrm{E}_{\text {corr }}\right)$, pitting potential $\left(\mathrm{E}_{\mathrm{pit}}\right)$, and corrosion current density $\left(\mathrm{I}_{\text {corr }}\right)$ ) compared to other literatures could be contributed by several factors. Fabrication process (MIM vs wrought) can cause the difference in density of materials and chromium content. Difference aging heat treatment processes can cause the difference in $\mathrm{Cu}$-rich precipitate size and chromium segregation. Corrosive medium can also alter the reactions that occur during corrosion. 


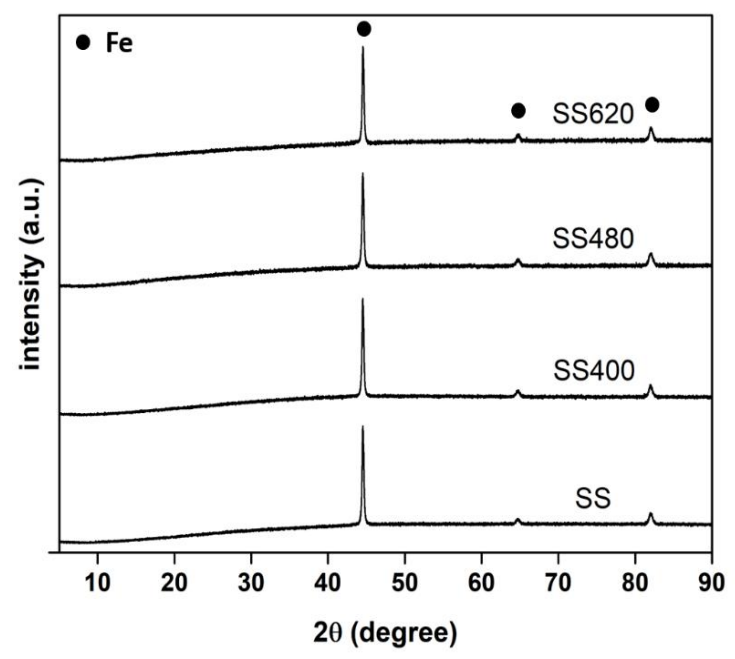

FIGURE 1. XRD patterns of 17-4PH stainless steel sample with different aging heat treatments

(a)

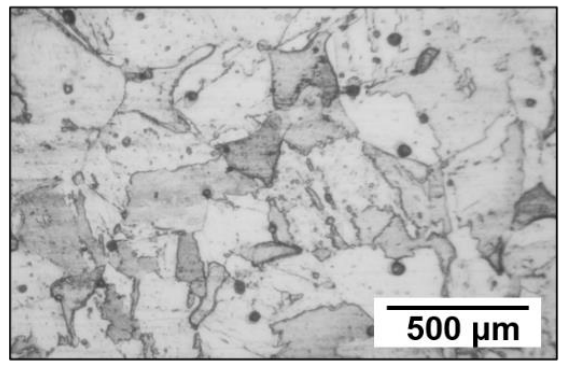

(c)

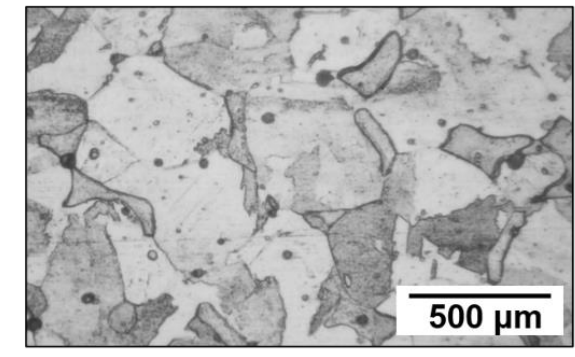

(b)

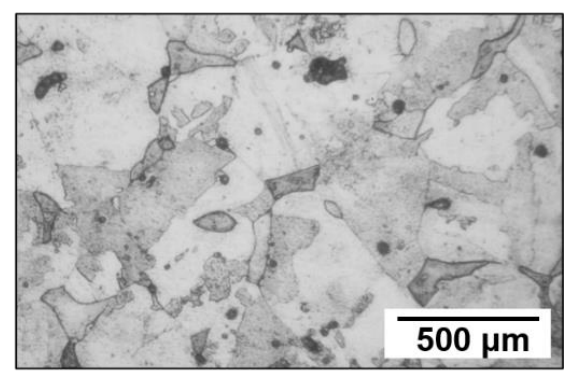

(d)

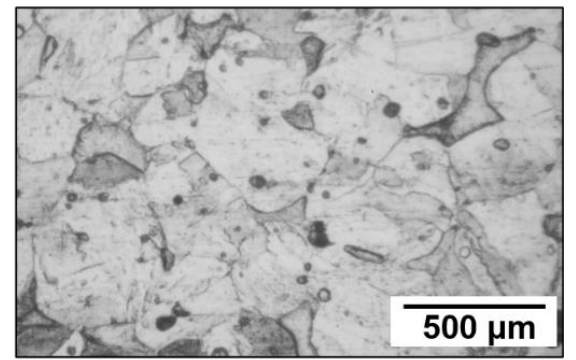

FIGURE 2. Optical micrographs of 17-4PH stainless steel sample with different aging heat treatments (a) SS, (b) SS400, (c) SS480 and (d) SS620 


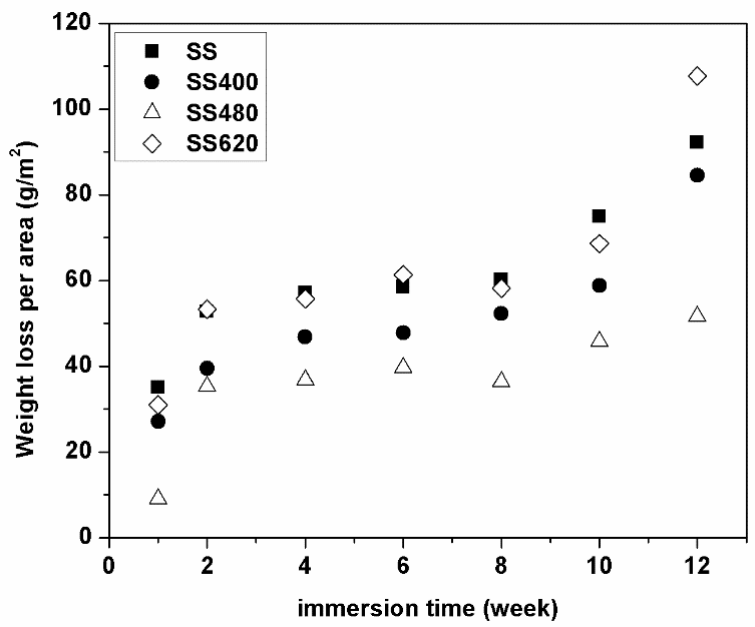

FIGURE 3. Weight loss per unit area of 17-4 PH stainless steel aged at different conditions immersed in artificial saliva

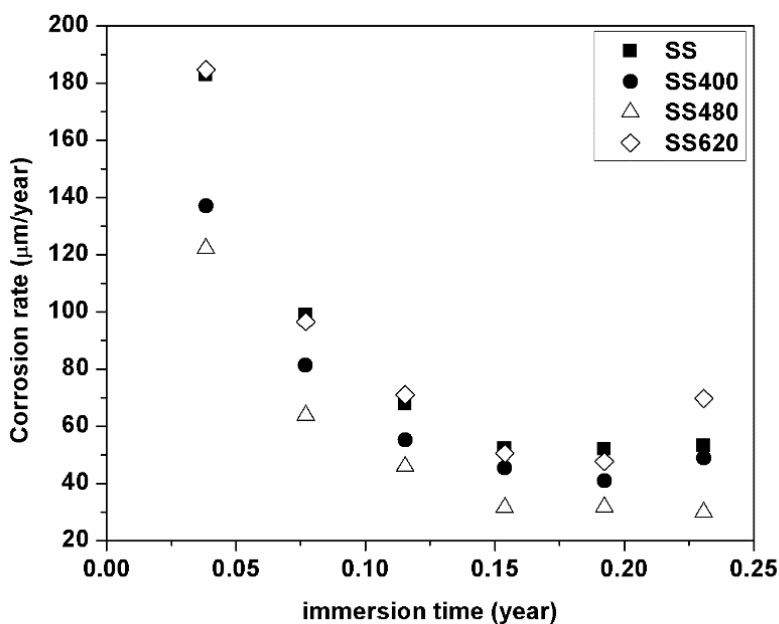

FIGURE 4. Corrosion rate of 17-4 PH stainless steel aged at different conditions immersed in artificial saliva

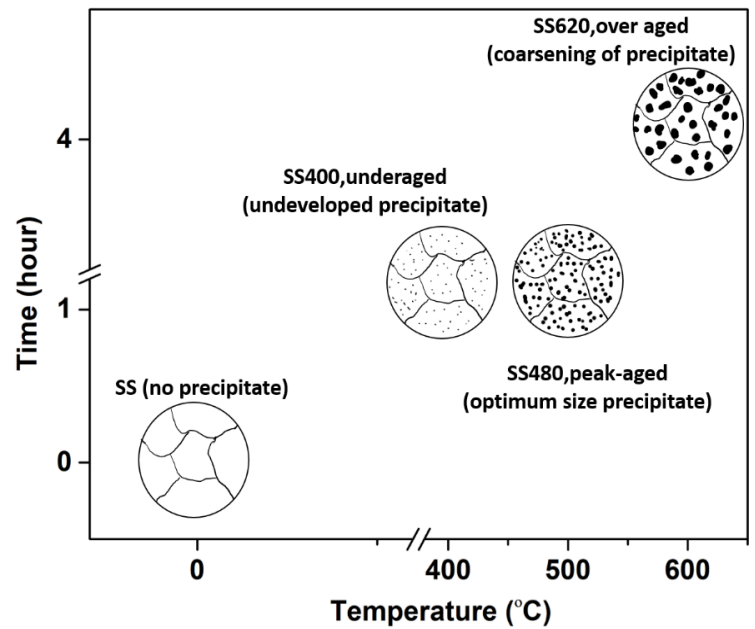

FIGURE 5. Schematic illustrates the Cu-rich phase precipitate in SS, underaged (SS400), peak-aged (SS480), and overaged (SS680) samples 

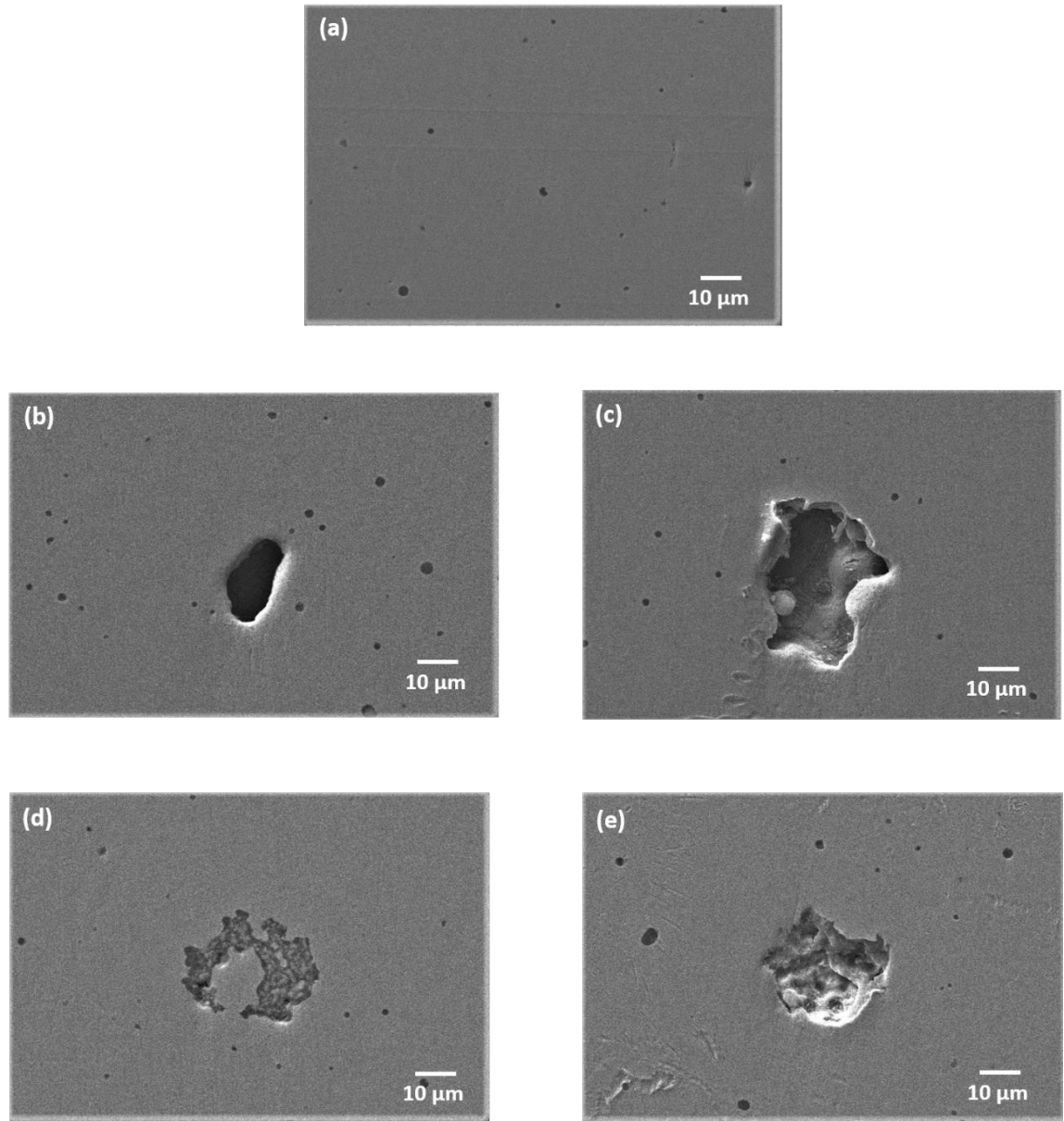

FIGURE 6. SEM images showing (a) polished surface of unaged sample, (b-e) localized corrosion after 12 weeks of immersion in SS, SS420, SS480 and SS620, respectively

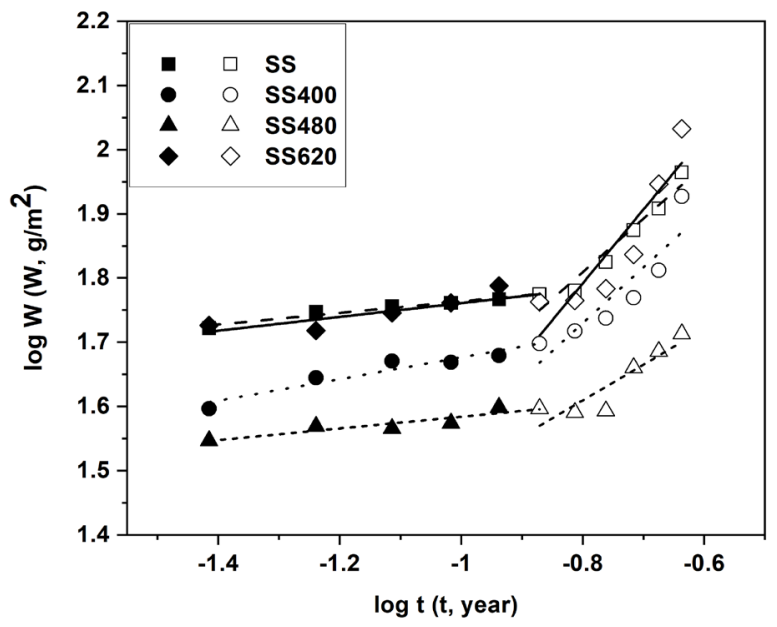

FIGURE 7. Log W-log t plot for 17-4 PH stainless steel aged at different conditions immersed in artificial saliva 


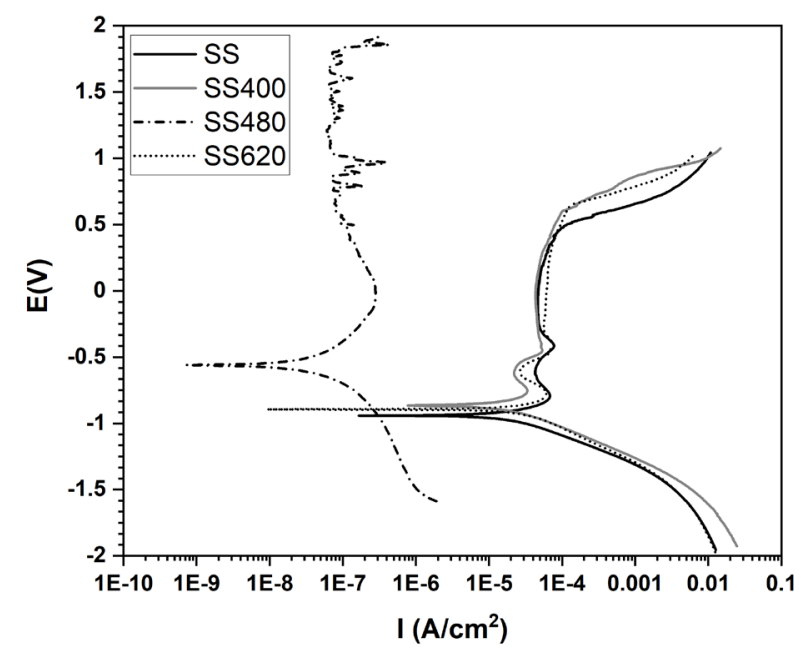

FIGURE 8. Potentiodynamic polarization curves of 17-4 PH stainless steel aged at different conditions in artificial saliva

TABLE 3. Corrosion constants $\left(\mathrm{n}_{1}\right.$ and $\left.\mathrm{n}_{2}\right)$ determined by bimodal function

\begin{tabular}{ccccc}
\hline $\begin{array}{c}\text { Corrosion } \\
\text { constant }\end{array}$ & SS & SS400 & SS480 & SS620 \\
\hline $\mathrm{n}_{1}$ & 0.09 & 0.16 & 0.09 & 0.11 \\
$\mathrm{n}_{2}$ & 0.83 & 0.87 & 0.55 & 1.15 \\
\hline
\end{tabular}

TABLE 4. Electrochemical data of 17-4PH stainless steel aged at different conditions

\begin{tabular}{cccc}
\hline Sample & $\mathrm{E}_{\text {corr }}[\mathrm{V}]$ & $\mathrm{E}_{\mathrm{pit}}[\mathrm{V}]$ & $\mathrm{I}_{\text {corr }}\left(\mu \mathrm{Acm}^{-2}\right)$ \\
\hline SS & -0.94 & 0.71 & 26.5 \\
SS400 & -0.87 & 0.61 & 32.9 \\
& & & \\
SS480 & -0.56 & - & 0.281 \\
& & & \\
SS620 & -0.89 & 0.65 & 28.5 \\
\hline
\end{tabular}

\section{CONCLUSION}

The corrosion behavior of the sintered 17-4PH stainless steel aged at different conditions in artificial saliva were investigated. The 17-4PH stainless steel suffered from pitting corrosion as existing pores initiate pit. The samples aged at $480{ }^{\circ} \mathrm{C}$ for $1 \mathrm{~h}$ exhibited the highest corrosion resistance in both immersion test and electrochemical measurement. The corrosion kinetics is consistent with the bimodal function model. The corrosion constant of the first stage and second stage are in the range of 0.09-0.16 and $0.50-1.15$, respectively. The mechanism is proposed that at the first stage, the diffusion process decreases with 
time, as the corrosion product becomes compact. At the second stage, the corrosion dissolution is accelerated as the corrosion product detachment occurs.

\section{ACKNOWLEDGEMENTS}

This work has been financially supported by Mae Fah Luang University research fund (Grant\# 631B01014). The author would like to thank Dr. Aunchalee Manonukul from National Metal and Materials Technology Center (MTEC) for providing the 17-4PH stainless steel samples.

\section{REFERENCES}

Al-Moubaraki, A.H. \& Al-Rushud, H.H. 2018. The red sea as a corrosive environment: Corrosion rates and corrosion mechanism of aluminum alloys 7075, 2024, and 6061 . International Journal of Corrosion 2018: 1-16.

Al-Moubaraki, A.H., Al-Judaibi, A. \& Asiri, M. 2014. Corrosion of C-steel in the red sea: Effect of immersion time and inhibitor concentration. International Journal of Electrochemical Science 10(5): 4252-4278.

Chung, C. \& Tzeng, Y. 2019. Effects of aging treatment on the precipitation behavior of $\varepsilon-\mathrm{Cu}$ phase and mechanical properties of metal injection molding 17-4PH stainless steel. Materials Letters 237: 228-231.

Costa, I., Franco, C.V., Kunioshi, C.T. \& Rossi, J.L. 2006. Corrosion resistance of injection-molded 17-4PH steel in sodium chloride solution. Corrosion 62(4): 357-365.

Escobar, C.G.N., Domingues, J.A., Gomes, J.C. \& Cohelo, U. 2017. Effects of diferent salivary $\mathrm{pH}$ on the surface and roughness of different orthodontic wires. Journal of Research in Dentistry 2(6): 527-536.

Frankel, G.S. 1998. Pitting corrosion of metals a review of the critical factors. Journal of The Electrochemical Society 145(8): 2186-2198.

Gülsoy, H.Ö., Salman, S. \& Özbek, S. 2004. Effect of FeB additions on sintering characteristics of injection moulded 17-4PH stainless steel powder. Journal of Materials Science 39(15): 4835-4840.

He, S. \& Jiang, D. 2018. Electrochemical behavior and properties of passive films on 304 stainless steel under high temperature and stress conditions. International Journal of Electrochemical Science 13: 5832-5849.

Hsiao, C.N., Chiou, C.S. \& Yang, J.R. 2002. Aging reactions in a 17-4PH stainless steel. Materials Chemistry and Physics 74(2): 134-142.

Li, L., Wang, J., Yan, J., Fan, H., Zeng, Bo., Li, X. \& Dong, H. 2020. Low-temperature oxy-nitriding of AISI 304 austenitic stainless steel for combat corrosion and wear in $\mathrm{HCl}$ medium. Metallurgical and Materials Transactions A: Physical Metallurgy and Materials Science 51(1): 419-435.

Liu, D., Liu, D., Zhang, X., Liu, C. \& Ao, N. 2018. Surface nanocrystallization of 17-4 precipitation-hardening stainless steel subjected to ultrasonic surface rolling process. Materials Science and Engineering A 726: 69-81.
Manonukul, A., Likityingwara, W., Rungkiatnawin, P., Muenya, N., Amoranan, S., Kittinantapol, W. \& Supapunt, S. 2007. Study of recycled and virgin compounded metal injection moulded feedstock for stainless steel 630. Journal of Solid Machanic and Material Engineering 1(4): 411-420.

Melchers, R.E. 2019. Predicting long-term corrosion of metal alloys in physical infrastructure. npj Materials Degradation 3(1): 1-7.

Melchers, R.E. 2014. Bi-modal trend in the long-term corrosion of aluminium alloys. Corrosion Science 82: 239-247.

Morcillo, M., Chico, B., Díaz, I., Cano, H. \& Fuente, D.D.L 2013. Atmospheric corrosion data of weathering steels. A review. Corrosion Science 77: 6-24.

Mudali, U.K., Bhaduri, A.K. \& Gnanamoorthy, J.B. 1990. Localised corrosion behaviour of 17-4 PH stainless steel. Materials Science and Technology 6(5): 475-481.

Murayama, M., Katayama, Y. \& Hono, K. 1999. Microstructural evolution in a $17-4 \mathrm{PH}$ stainless steel after aging at $400^{\circ} \mathrm{C}$. Metallurgical and Materials Transactions A: Physical Metallurgy and Materials Science 30(2): 345-353.

Raja, K.S. \& Prasad, R.K. 1995. Intergranular and general corrosion behaviour of 17-4PH weldments. Materials and Corrosion 46(9): 534-538.

Renita, D., Rajendran, S. \& Chattree, A. 2017. Influence of artificial saliva on the corrosion behavior of dental alloys: A review. Indian Journal of Advances in Chemical Science 4(4): 478-483.

Shoushtari, M.R.T. 2010. Effect of ageing heat treatment on corrosion behavior of $17-4 \mathrm{PH}$ stainless steel in $3.5 \% \mathrm{NaCl}$ International Journal of Iron and Steel of Iran 7(1): 33-36.

Sobral, A.V.C., Ristow, W., Correa, O.V., Franco, C.V. \& Costa, I. 2001. Corrosion behaviour of injection moulded $316 \mathrm{~L}$ and $17-4 \mathrm{PH}$ stainless steels in a sodium chloride solution. Key Engineering Materials 189-191: 667-672.

Suri, P., Smarslok, B.P. \& German, R.M. 2006. Impact properties of sintered and wrought $17-4 \mathrm{PH}$ stainless steel. Powder Metallurgy 49(1): 40-47.

Szewczyk-Nykiel, A. 2014 The effect of the addition of boron on the densification, microstructure and properties of sintered 17-4PH stainless steel. Technical Transactions 13: 85-96.

Szewczyk-Nykiel, A. \& Kazior, J. 2017. Effect of aging temperature on corrosion behavior of sintered 17-4 $\mathrm{PH}$ stainless steel in dilute sulfuric acid solution. Journal of Materials Engineering and Performance 26(7): 3450-3456.

Viswanathan, U.K., Banerjee, S. \& Krishnan, R. 1988. Effects of aging on the microstructure of 17-4 PH stainless steel. Materials Science and Engineering 104: 181-189.

Wang, J.H., Wei, F.I., Chang, Y.S. \& Shih, H.C. 1997. The corrosion mechanism of carbon steel in $\mathrm{SO}_{2}$ polluten atmospheres. Materials Chemistry and Physics 47(1): 1-8.

Wu, Y., Blaine, D., Schlaefer, C., Marx, B. \& German, R.M. 2002. Sintering densification and microstructural evolution of injection molding grade 17-4PH stainless steel powder. Metallurgical and Materials Transactions A: Physical Metallurgy and Materials Science 33(7): 2185-2194.

Yoo, W.D., Lee, J.H., Youn, K.T. \& Rhyim, Y.M. 2006. Study on the microstructure and mechanical properties of $17-4 \mathrm{PH}$ 
stainless steel depending on heat treatment and aging time. Solid State Phenomena 118: 15-20.

Zhang, H. 1992. Powder injection moulding (PIM) of 17-4PH stainless steel. Metal Powder Report 47(10): 59.

Zhang, M. \& Chu, Q. 2012. Heat treatment of 17-4PH stainless steel. Heat Treatment of Metals 37(9): 8-11.

Ziewiec, A., Zielińska-Lipiec, A. \& Tasak, E. 2014. Microstructure of welded joints of X5CrNiCuNb16-4 (17-4 PH) martensitic stainlees steel after heat treatment. Archives of Metallurgy and Materials 59: 965-970.

Onthida Kosasang* \& Somwan Chumphongphan

School of Science

Mae Fah Luang University

Chiang Rai 57100

Thailand
Onthida Kosasang*, Manutchaya Wongkaewmoon \& Somwan Chumphongphan

Center of Innovative Materials for Sustainability (iMatS)

School of Science

Mae Fah Luang University

Chiang Rai 57100

Thailand

*Corresponding author; email: onthida.kos@mfu.ac.th

Received: 11 June 2020

Accepted: 7 September 2020 